\title{
Adaptability, stability, productivity and genetic parameters in slash pine second-generation families in early age
}

\author{
M.K. Pagliarini' ${ }^{1}$, W.S. Kieras ${ }^{2}$, J.P. Moreira ${ }^{1}$, V.A. Sousa ${ }^{3}$, J.Y. Shimizu ${ }^{4}$, M.L.T. Moraes ${ }^{1}$, E. Furlani Jr. ${ }^{1}$, \\ and A.V. Aguiar ${ }^{3}$
}

'Faculdade de Engenharia de Ilha Solteira, Universidade Estadual Paulista "Júlio de Mesquita Filho", Avenida Brasil, 56, CEP 15385-000, Ilha Solteira, SP, Brasil.

${ }^{2}$ Universidade Federal do Paraná, Curitiba, Paraná.

${ }^{3}$ Embrapa Florestas, Estrada Ribeira, Km 111, CEP 83411-000, Colombo, Paraná,

${ }^{4}$ Doctor in Forest Breeding

* Corresponding author: M.K. Pagliarini, E-mail: max.pagliarini@gmail.com

\begin{abstract}
The study was conducted to estimate the stability, adaptability, productivity and genetic parameters in Slash pine second-generation half-sib families, considering phenotypic traits in early age. Forty-four families from a first generation seed orchard in Colombo-PR, Brazil, were used in this study. Two progenies tests were established in a randomized complete block design. The first test was implemented in March 2009 in Ribeirão Branco, São Paulo state, containing 40 blocks, one tree per plot, 44 treatments (progenies) and 6 controls. Another test was implemented in Ponta Grossa, Paraná state, using the same experimental design and number of plants per plot, and with 24 treatments, 32 blocks. The growth traits evaluated were total height, diameter at breast height ( $\mathrm{dbh}$ ) and wood volume, within five years. The form traits evaluated were stem form, branch thickness, branch angle, number of branches, fork and fox tail five years after planting. Deviance analysis and estimates of stability, adaptability, productivity and genetic parameters were performed using the methods of best linear unbiased predictor (BLUP) and residual maximum likelihood (REML). There was significant variation among progenies for growth and form traits. Considerable genetic variation was detected mainly for wood volume. High coefficients of genetic variation and heritability showed low environmental influence on phenotypic variation, which is important for the prediction of genetic gain by selection. Crosses between different progenies individuals groups will be prioritized for obtaining heterotics genotypes and increase the probability of obtaining high specific combining ability.
\end{abstract}

Keywords: Pinus elliottii Engelm. var. elliottii, seed production, selection gain, REML/BLUP, genotype x environment interaction

\section{Introduction}

In Brazil, the most limiting climatic factors for pine cultivation are temperature and precipitation. Based on these effects observation under reforestation areas (experimental tests) two growing areas have been established for pine species in Brazil tropical and temperate regions. For the second region Pinus elliottii adapted well to environmental conditions making it the second most widely planted species of the genus Pinus for wood production and first for resin extraction (Romanelli and Sebbenn, 2004).

Slash pine (Pinus elliottii Engelm var. elliottii) occurs on coastal plains all over the Indian River Lagoon area, and in freshwater upland areas. It may be found on coastal plains from South Carolina to Central Florida, and west to Louisiana. Slash pine was introduced in Kentucky, Virginia and eastern Texas in the 1900's, and now reproduces naturally within these states (United States Department Of Agriculture - USDA, 2004).

The introduction of exotic species in Brazil, as Slash pine have driven the forest breeding mainly for increasing productivity, obtaining raw materials of higher quality, improving species to adaptive conditions, tolerance to pests and diseases and maintaining genetic variability (Martins-Corder et al., 1996). More specific issues such as genotype $x$ environment interaction (GxE) were less prioritized, therefore, it is indispensable to evaluate the maximum number of environments and adoption of more rigorous methods of improvement as possible in order to obtain data with high accuracy, which allows selection of the best materials to be multiplied on a commercial scale for many environments. To make this recommendation as reliable as possible, a detailed study is required for genotypes temporal stability and with regard to their most important economically traits (Cruz, 2006). Analysis of adaptability, stability and productivity are statistical procedures to identify more stable and performance materials that respond 
predictably to environmental variations (Silva and Duarte, 2006).

The adaptability refers to genotypes ability of responding to environmental stimulation and the stability is genotypes ability of maintaining the same performance under various environmental conditions (Alwala et al., 2010). Adaptability and stability analysis allows the identification of predictable genotypes behaviours (production) in different environments (Cruz et al., 2004). Considering the range of planting zones and the existence of diversity in used material in commercial pine plantations more detailed investigation in relation to the behaviour of genotypes will generate important information for establishment of more productive plantings. Furthermore, all intents and purposes need to be considered to estimate adaptability, stability and productivity for forest species trials (Pereira et al., 1997). The use of biotechnology in many stages of the process and estimation of genetic parameters at early ages, especially genetic correlations, accuracies and heritability are the alternatives to reduce the selection cycle. Thus, silvicultural traits of economic interest in juvenile trees are measured in order to predict the performance of each individual in adulthood (Gonçalves et al., 1998). In this way, in forest improvement, early age selection has shown great advantage shortening the interval between generations by reducing the breeding cycle. More genetic gain may be obtained per unit of time (year) if a strong genetic correlation exists between the initial stages and the end of the production cycle (Nanson, 1970; Lambeth, 1980; Mckeand, 1988; Matheson et al., 1994; Silva et al., 2014). Therefore, the study was conducted (i) to estimate the stability, adaptability, productivity, genetic diversity and genetic parameters in slash pine second-generation halfsibs families considering the phenotypic traits at early age, and (ii) to identify more productive genotypes for commercial plantations in the two major Brazilian states with the largest acreage of the species, São Paulo and Paraná.

\section{Material and Methods}

Forty-four families originated from a slash pine first generation seed orchard established in Colombo, Paraná state, Brazil were used in this study. The seedlings were produced in municipality of Ribeirão Branco, São Paulo state in 2008. In March of 2009 two progeny tests were installed, one in Ponta Grossa (PG), in Paraná state and another in Ribeirão Branco (RB), São Paulo State (Table 1).

Data were measured five years after planting for traits: survival rate; total height, diameter at breast height (dbh) and wood volume, computed based on the total height of and dbh, according to the following equation:

$$
V O L=\frac{\pi(D B H)^{2} \cdot F F}{40000} T H
$$

where VOL was wood volume, FF was the stem form factor and $\mathrm{TH}$ was total height. The height trait was measured using a telescopic ruler, circumference at breast height was measured with a tape calculating from these values the diameter at breast height and survival was adopted " 1 " to alive and " 0 " to
Table 1

Details of slash pine family tests deployed in municipalities of Ribeirão Branco and Ponta Grossa, Brazil

\begin{tabular}{ccc} 
& Ribeirão Branco & Ponta Grossa \\
Progenies number & 44 & 24 \\
Blocks & 40 & 32 \\
Controls & 6 & - \\
Spacing & \multicolumn{2}{c}{$3 \mathrm{~m} \times 3 \mathrm{~m}$} \\
Establishment date & \multicolumn{2}{c}{ March $/ 2009$} \\
Border & \multicolumn{2}{c}{ lines } \\
Latitude & $25^{\circ} 05^{\prime} 42^{\prime \prime} \mathrm{S}$ & $24^{\circ} 13^{\prime} 15^{\prime \prime} \mathrm{S}$ \\
Longitude & $50^{\circ} 09^{\prime} 43^{\prime \prime} \mathrm{W}$ & $48^{\circ} 45^{\prime} 56^{\prime \prime} \mathrm{W}$ \\
Altitude & $969 \mathrm{~m}$ & $875 \mathrm{~m}$ \\
Rainfall & $1,346 \mathrm{~mm}$ & $1,495 \mathrm{~mm}$ \\
ding to Koeppen & $\mathrm{Cfb}$ & $\mathrm{Cfb}$ \\
Average temperature & $18^{\circ} \mathrm{C}$ & $17.5^{\circ} \mathrm{C}$ \\
Soil type & $\mathrm{Cambissolo}$ & $\mathrm{Cambissolo}$
\end{tabular}

dead plants. Form traits were visually scored as follows (Table 2).

\section{Estimates of variance components and genetic parameters}

Estimates of variance and genetic parameters components were obtained by REML/BLUP method (restricted maximum likelihood/best linear unbiased prediction) from unbalanced data, using genetic-statistical SELEGEN-REML/BLUP program (Resende, 2007a). Different models were used to perform statistical analyses and estimate genetic parameters, as described below.

\section{Table 2}

Scoring for form traits of slash pine families in municipalities of Ribeirão Branco and Ponta Grossa, Brazil

\begin{tabular}{|c|c|c|c|c|}
\hline & \multicolumn{2}{|c|}{ Scale } & \multicolumn{2}{|c|}{ Description } \\
\hline Traits & RB & PG & RB & PG \\
\hline $\begin{array}{l}\text { Stem } \\
\text { straightness }\end{array}$ & $1-3$ & $1-5$ & $\begin{array}{l}1=\text { most crooked } \\
\text { steams, } 3=\text { straigh- } \\
\text { test stems }\end{array}$ & $\begin{array}{l}1=\text { most crooked } \\
\text { steams, } 5=\text { straigh- } \\
\text { test stems }\end{array}$ \\
\hline $\begin{array}{l}\text { Branch } \\
\text { thickness }\end{array}$ & \multicolumn{2}{|c|}{$1-3$} & \multicolumn{2}{|c|}{$1=$ thicker, $3=$ thinner } \\
\hline $\begin{array}{l}\text { Branch } \\
\text { angle }\end{array}$ & \multicolumn{2}{|c|}{$1-3$} & \multicolumn{2}{|c|}{$\begin{array}{c}1=\text { less than } 45^{\circ}, 2=\text { greater than } 45^{\circ} \text { and } 3= \\
\text { approximately } 90^{\circ}\end{array}$} \\
\hline $\begin{array}{l}\text { Number of } \\
\text { branches }\end{array}$ & \multicolumn{2}{|c|}{$1-7$} & $\begin{array}{c}1=42 \text { to } 48 \text { branches, } \\
7=1 \text { to } 6 \text { branches }\end{array}$ & $\begin{array}{c}1=17 \text { to } 18 \text { branches, } \\
7=0 \text { to } 2 \text { branches }\end{array}$ \\
\hline Fork & \multicolumn{2}{|c|}{1 and 2} & \multicolumn{2}{|c|}{ " 1 " for absence and " 2 " for presence } \\
\hline $\begin{array}{l}\text { Fox tail (only } \\
\text { for Ponta } \\
\text { Grossa trial) }\end{array}$ & \multicolumn{2}{|c|}{1 and 2} & \multicolumn{2}{|c|}{ "1" for absence and " 2 " for presence } \\
\hline
\end{tabular}




\section{Individual analysis and estimation of genetic parameters}

The model applied to carried out the deviance analysis of halfsib families tests was randomized complete block, one tree per plot, one site: $y=X_{r}+Z_{a}+e$, where $y$ is the data vector $r$ is the vector of replication effects (assumed to be fixed) added to the general average, $a$ is the vector of individual additive genetic effects (assumed to be random), e is the error vector or residues (random). The capital letters represent the incidence matrices for these purposes. To use this model, it was necessary to assume that the open pollinated progenies of slash pine are half-sibs. Thus, the first step was carried out analysis considering all treatments including the control (for RB). Later, controls were removed, proceeding further analysis to estimate the parameters and predict genetic values.

The significance test was performed using the likelihood ratio test (LRT), obtained by the difference between deviances for models with and without effect to be tested and using the chi-square test. The genetic parameters estimated were:

a) Narrow sense individual heritability:

$$
h_{a}^{2}=\frac{\sigma_{a}^{2}}{\sigma_{a}^{2}+\sigma_{e}^{2}}
$$

b) Average heritability of progenies:

$$
h_{m}^{2}=\frac{\left[1+(n-1) \rho_{a}\right] h^{2}}{1+(n-1)\left(\rho_{a} h^{2}\right)}
$$

c) Accuracy:

$$
r_{\hat{a} a}=\sqrt{\frac{n}{n+\left(\frac{4-h_{a}^{2}}{h_{a}^{2}}\right)}}
$$

d) Individual phenotypic variance:

$$
\hat{\sigma}_{f}^{2}=\hat{\sigma}_{a}^{2}+\hat{\sigma}_{e}^{2}
$$

e) Coefficient of individual genetic variance:

$$
C V_{g i}=\frac{100 \cdot \sqrt{\overline{\sigma_{a}^{2}}}}{\mu}
$$

f) Coefficient of genetic variation between progenies:

$$
C V_{g p}=100 \cdot \frac{\sqrt{0,25 \hat{\sigma}_{a}^{2}}}{\mu}
$$

g) Coefficient of experimental variation:

$$
C V_{e}=100 \cdot \frac{\sqrt{Q M_{r e s}}}{\mu}
$$

\section{Effective sizes and expected selection gains}

To select superior genotypes for commercial plantations and seedling seed orchards formation were simulated different selection methods from progeny individual additive genetic values classification of each tests and progenies genetic classification. For this, volume breeding values were used. After obtaining individual additive values for selected trees, according to individual classification obtained by BLUP procedure, genetic gain in percentage was estimated by the expression: $\mathrm{SG}(\%)=$ mean of the additive genetic values of selected individuals $/ \mathrm{m}$ ) $\times 100$, where $\mathrm{m}$ is the overall average of the experiment for a given trait. Selection strategies were: i) selecting of the 80 best individuals from each site to form a clonal orchard; ii) selecting the two best individuals per progeny for the next breeding cycle and iii) selecting the best $50 \%$ individuals per families to form a seedling seed orchard. To guide the selection strategy adopted in order to avoid excessive loss of genetic variability after application of the proposed selection methods, the effective population size and genetic diversity were estimated from the equation proposed by RESENDE (2007b).

\section{Trait-trait and age-age genetic and phenotypic correlations}

Genetic and phenotypic correlations between traits and ages were undertaken, using SELEGEN-REML/BLUP (Resende, 2007a).

\section{Productivity, stability and adaptability}

For joint analysis, considering the two sites, was used statistical procedure MHPRVG (harmonic mean of the relative performance of the breeding values) predicted by BLUP, according to Resende (2007b). The model used was: $y=X_{r}+Z_{g}+W_{i}+e$, where $y$ is the data vector $r$ is the vector of replication effects (assumed to be fixed) added to the general average, $g$ is the vector of genotypic effects (assumed to be random), $\mathrm{i}$ is the vector of the effects of genotype $x$ environment interaction (random) and $e$ is the vector of errors or residues (random). The capital letters represent the incidence matrices for these purposes. The vector $r$ includes all measurements in all replications in multiple sites simultaneously and adjusts to all these effects and their interactions (Resende, 2007b). In addition to the narrow sense individual heritability $\left(h_{a}^{2}\right)$, average heritability of progenies $\left(h_{m}^{2}\right)$, accuracy $\left(r_{\hat{a} a}\right)$, coefficient of individual additive genetic variation $\left(C V_{g i}\right)$ and coefficient of residual variation $\left(C V_{e}\right)$ were estimated:

a) Coefficient of determination for aenotype $x$ environment interaction:

$$
C_{i n t}^{2}=\frac{\sigma_{i n t}^{2}}{\sigma_{A}^{2}}
$$

b) Genotypic correlation between progenies in different environments (Type b correlation):

$$
r_{\text {gloc }}=\frac{\sigma_{A}^{2}}{\sigma_{A}^{2}+\sigma_{i n t}^{2}}
$$




\section{Results and discussion}

\section{Individual deviance analysis and genetic parame- ters estimation}

Survival rate was high in Ribeirão Branco (RB) trial five years after planting (95\%) while in Ponta Grossa (PG) was relatively low, only $65 \%$ (Fig. 1). Yang et al. (2013) showed the first years are important to plant recover the root system and adapt to the new environment, if it does not occur, mortality rate of seedlings may be high, as observed in PG. Furthermore, lack of water in first weeks after planting may be responsible by plant mortality, the first month after planting there was less rainfall in relation to the normal April month at PG. According to Schultz (1997), pine productivity is positively associated to places with mild temperatures and mostly smaller water deficit.

The mean total height, $\mathrm{dbh}$ and volume ranged from 1.08 to $5.82 \mathrm{~m}, 7.38$ to $10.73 \mathrm{~cm}$ and 0.01 to $0.03 \mathrm{~m}^{3} \mathrm{arv}^{-1}$ and 0.91 to $6.04 \mathrm{~m}, 7.35$ to $11.52 \mathrm{~cm}$ and 0.01 to $0.03 \mathrm{~m}^{3} \mathrm{arv}^{-1}$, in RB and PG, respectively. There was little difference in relation to secondgeneration slash pine progenies productive performance in both assays. Significant variation among progenies was observed for most of evaluated growth traits at 5 and $1 \%$ of probability, except for the survival trait in both tests and one year after planting in PG trial (Fig. 1).

In RB, commercial controls of slash pine were planted with experiment aiming to compare performance of established trees with tested progenies, which can be as adaptable as the previous one. The best commercial control was 1123; however, comparing to progenies it is possible to notice, for wood volume at age three only two progenies were better than this control (C-098-1 and C-100-2). Two years later, at age five, the tested progenies were more adapted to new environment and in this case, it is possible to highlight five better progenies than 1123, such as C-063-2, C-098-1, C-228, C-001-1 and C-100-2.

In relation to form traits, significant statistical difference were detected for stem straightness and number of branches for RB and stem straightness, branch thickness, branch angle and fox tail to PG (Fig. 2). Stem form traits mean were similar to both sites, except stem straightness and number of branches. PG produced trees with score mean of 3.34 and RB of 2.11, in other words, greater numbers indicates straighter trees.

Experimental design showed good precision for majority growth and form traits (Fig. 3 and 4). Coefficient of experimental variation $\left(C V_{e}\right)$ ranging from $8.6 \%$ (fork) to $28.9 \%$ (stem straightness) for RB and $8.3 \%$ (number of branches) to $34.7 \%$ (branch thickness) for PG (Fig. 04). Experimental variation between 10 to $20 \%$ can be considered low in field tests due plant competition (Pimentel-Gomes and Garcia, 2002). These results indicate robust experimental control and accuracy in genetic parameters estimation.

Considerable genetic variation for volume may be found across the magnitudes of coefficient of individual genetic variation $\left(C V_{g i}\right)$ which ranged from 14.3 to $16.2 \%$ in RB and from 33.8 to $31.8 \%$ in PG (Fig. 03), as stem straightness and branch thickness for PG trial (14.7\% and $21.8 \%$, respectively, Fig. 04). These values have provided high magnitude of individual heritability. Other traits expressed medium to low magnitude for
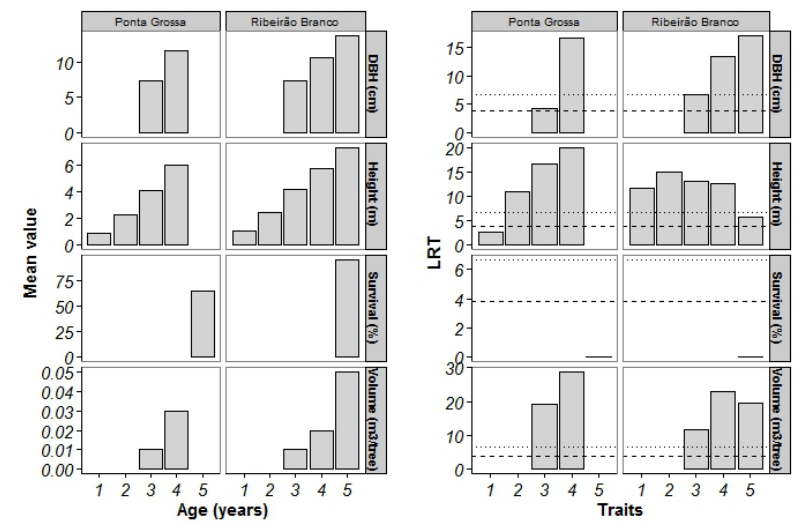

Figure 1

Mean values, likelihood ratio test (LRT) and significance levels for slash pine growth traits in municipalities of Ribeirão Branco and Ponta Grossa, Brazil. (LRT above dashed line = $\mathrm{p}<0.05$; above dotted line $=\mathrm{p}<0.01$ and below dashed line $=$ not significant
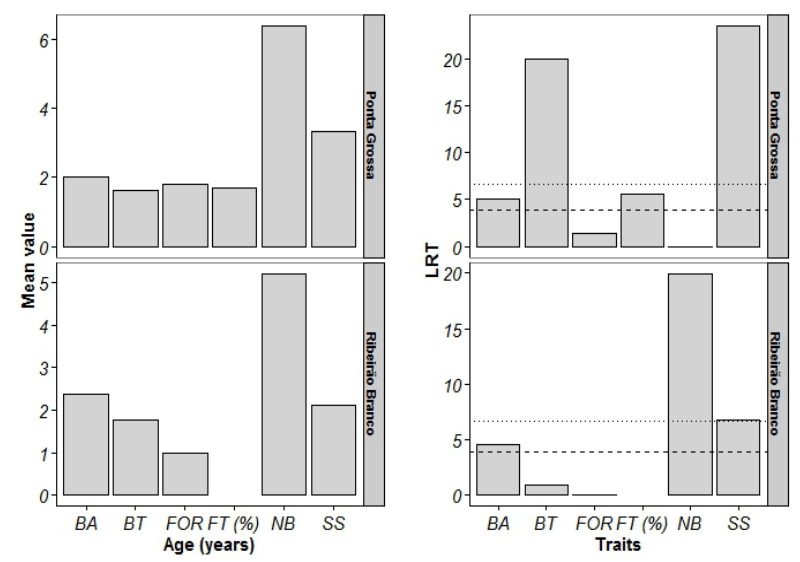

Figure 2

Mean values, likelihood ratio test (LRT) and significance levels for slash pine form traits in municipalities of Ribeirão Branco and Ponta Grossa, Brazil. (LRT above dashed line = $\mathrm{p}<0.05$; above dotted line $=\mathrm{p}<0.01$ and below dashed line = not significant - BA: branch angle, BT: branch thickness, FOR: fork, FT: fox tail, NB: number of branches, SS: stem straightness)

genetic variation. For height $C V_{g i}$ ranged from 3.3 to $6.5 \%$ in $\mathrm{RB}$ and 9.0 to $11.6 \%$ in PG. For dbh, estimates ranged between $4.986 \%$ to $5.4 \%$ in the first site and 9.0 to $11.9 \%$ in the second (Fig. 03). Fork presented low $C V_{g i}$ of $1.9 \%$ (RB) and $5.9 \%$ (PG) (Fig. 04). These estimates were considered high in relation to those reported in other studies of slash pine (Romanelli and Sebbenn, 2004; Sebbenn et al., 2008), P. caribaea var. bahamensis (Sebbenn et al., 1994; Freitas et al., 2005), P. tecunumanii (Sebbenn et al., 2005) and P. sylvestris (FRIES, 2012). In contrast, Gapare at al. (2012) obtained genetic variation for $P$. radiata closer to PG trail, but higher than RB. Thus, the results of this study confirm the genetic potential of theseis families in both tests for tree improvement by selection of the best families, 


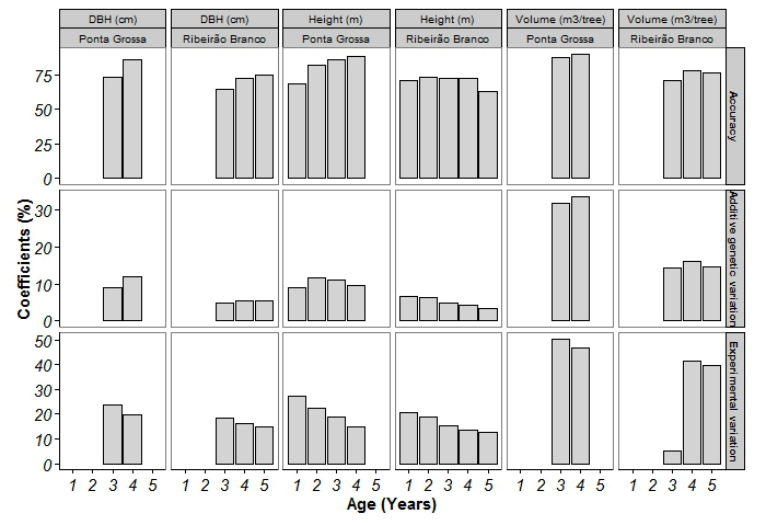

Figure 3

Coefficients of experimental variation, individual additive genetic variation and accuracy for growth traits for slash pine tests in municipalities of Ribeirão Branco and Ponta Grossa, Brazil

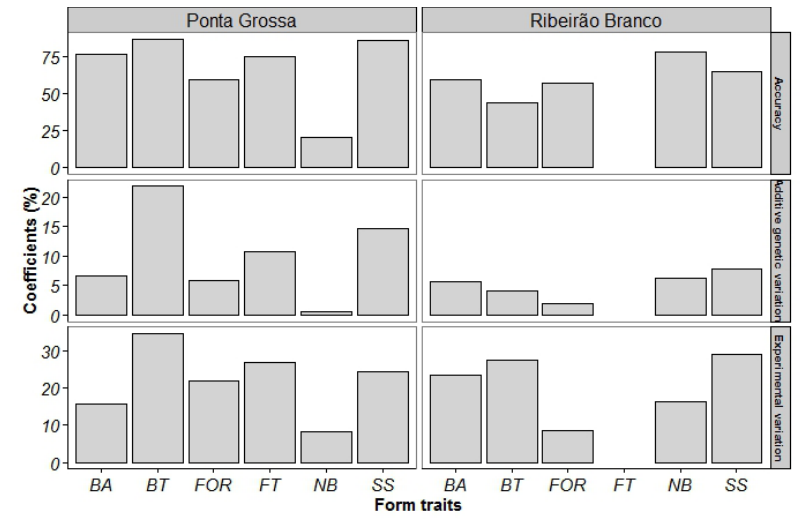

Figure 4

Coefficient of experimental variation, individual additive genetic variation and accuracy for slash pine progenies test in Ribeirão Branco-SP and Ponta Grossa-PR, Brazil. BA: branch angle, BT: branch thickness, FOR: fork, FT: fox tail, NB: number of branches, SS: stem straightness

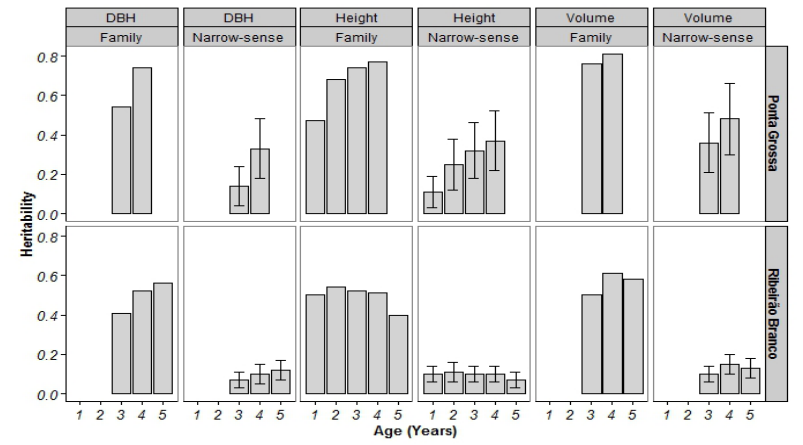

Figure 5

Narrow-sense individual heritability and family heritability mean for slash pine growth traits in municipalities of Ribeirão Branco and Ponta Grossa, Brazil especially for PG trial. Consequently, genotypes with the highest genetic values may be selected for commercial plantations and subsequent breeding generations. According to Miranda et al. (2015), higher the coefficient of genetic variation indicates greatest the chances of finding superior individuals.

Low genetic variation for fork can be related to binary factor. When the trait is binary both phenotypic and genetic variances may be affected by low frequency (Weng et al., 2015). According to quantitative genetic theories, estimation of heritability for binary traits is due to its incidence rate it means as lower the incidence as lower will be the phenotypic and genetic variances (Falconer and Mackay, 1996).

In early and intermediate stages of breeding programs, accuracy around $70 \%$ or higher are desirable. Most of growth traits in both tests showed values more than $70 \%$ (Fig. 03). Accuracy is the ratio between true genetic value and the predicted one and as higher the value, as higher the accuracy selection and genetic gain obtained. It can be considered low in the range from 0.10 to 0.40 , median from 0.41 to 0.70 and high if major than 0.70 (Resende et al., 1995). Consequently, the estimated accuracy for height can be considered median in RB and mid-high in PG. For dbh and volume accuracies were high for both locations (Fig. 03). Therefore, there is great expectation to reduce errors in the applied selection, and consequently, the selected material in the test will maintain their potential productive in commercial plantations and experiments.

Estimates of narrow sense individual heritability $\left(h_{a}^{2}\right)$, for RB site were considered low for all growth traits and moderate to high for number of branches. PG presented medium values for growth traits and moderate to high for stem straightness, branch thickness and branch angle (Fig. 5).

Dornan and Squillace (1974), Hodge and White (1992), Dieters et al. (1995) and Dieters (1996), previously reported low $h_{a}^{2}$. In the same way, Ettorii et al. (2004) found lower $h_{a}^{2}$ values in Pinus maximinoi as Silva et al. (2011) in P. caribaea var. caribaea. In the other hand, Parayi et al. (1996) and Zobel (1961) estimated median and high values also for $P$. caribaea var. caribaea at age 5, 8, 14 and 15; Aguiar et al. (2010) for Pinus greggii at 13 years old; and Missanjo et al. (2013) for Pinus kesiya at 18 years old in South Africa.

Wood volume is one of the most important trait to analyse in tree breeding programs. Individual narrow-sense heritabilities for RB were around 0.07 to 0.10 (Fig. 5), similar results found by Atwood et al. (2002) in 3 to 11 years old Pinus taeda families at Florida, Georgia, Mississippi and Alabama states. In PG, $h_{a}^{2}$ were higher and ranged between 0.36 to 0.48 (Fig. 5). When different works are analysed together the aim is not to compare and conclude one is better than the other, because there are several factors that may cause this differences, the main idea is to infer if the studied material is promising for a region. This study, the slash pine population presents good performance for two regions of planting. Furthermore, this population may be main seed source this species for wood companies, since that breeding program for this species is restricted some companies in Brazil.

In general, mean heritability among families for growth traits were higher in PG than RB (Fig. 5). The different weather 
Table 3

Selection strategies based on wood volume (VOL) and stem straightness (SS) for slash pine families in municipalities of Ribeirão Branco and Ponta Grossa, Brazil at 5 and 4 years old respectively. Strategy: I) Individual selection of 80 best trees; II) best two individuals per family and III) best $50 \%$ individuals per family

\begin{tabular}{|c|c|c|c|c|c|c|c|c|c|c|c|c|}
\hline Strategy & Site & $\begin{array}{c}\text { Trait } \\
\mathbf{s}\end{array}$ & $N$ & $N_{f o}$ & $N_{f}$ & $k_{f}$ & $\sigma_{k f}^{2}$ & $N_{e}$ & MEI & $S_{G}(\%)$ & $D^{\wedge}$ & $\mu$ \\
\hline \multirow{4}{*}{1} & \multirow{2}{*}{$\mathrm{RB}$} & Vol & 80 & 44 & 19 & 4.21 & 19.18 & 13.43 & 0.009 & 8.65 & 0.21 & 0.104 \\
\hline & & SS & 80 & 44 & 8 & 10.00 & 21.43 & 17.80 & 0.121 & 4.04 & 0.15 & 3.00 \\
\hline & \multirow{2}{*}{ PG } & Vol & 80 & 24 & 15 & 5.33 & 30.52 & 11.37 & 0.012 & 23.52 & 0.31 & 0.053 \\
\hline & & SS & 80 & 24 & 15 & 5.33 & 20.52 & 15.7 & 0.466 & 10.52 & 0.37 & 4.43 \\
\hline \multirow{4}{*}{ II } & \multirow{2}{*}{$\mathrm{RB}$} & Vol & 88 & 44 & 44 & 2.00 & 0.00 & 70.40 & 0.005 & 4.95 & 1.00 & 0.103 \\
\hline & & SS & 88 & 44 & 44 & 2.00 & 0.00 & 70.40 & 0.051 & 1.73 & 1.00 & 2.99 \\
\hline & \multirow{2}{*}{ PG } & Vol & 48 & 24 & 24 & 2.00 & 0.00 & 38.40 & 0.009 & 16.09 & 1.00 & 0.055 \\
\hline & & SS & 48 & 24 & 24 & 2.00 & 0.00 & 38.40 & 0.356 & 7.63 & 1.00 & 4.67 \\
\hline \multirow{4}{*}{ III } & \multirow{2}{*}{$\mathrm{RB}$} & Vol & 828 & 44 & 44 & 18.82 & 0.48 & 151.42 & 0.004 & 4.42 & 1.00 & 0.10 \\
\hline & & SS & 828 & 44 & 44 & 18.82 & 0.48 & 151.42 & 0.029 & 1.17 & 1.00 & 2.50 \\
\hline & \multirow{2}{*}{ PG } & Vol & 243 & 24 & 24 & 10.13 & 2.46 & 71.07 & 0.002 & 5.07 & 1.00 & 0.037 \\
\hline & & SS & 246 & 24 & 24 & 10.25 & 2.11 & 71.75 & 0.621 & 13.80 & 1.00 & 4.50 \\
\hline
\end{tabular}

Number of selected trees $(N)$; original number of progenies $\left(N_{f f}\right)$; number of selected progenies $\left(N_{f}\right)$; number of selected individuals per progeny $\left(k_{f}\right)$; variance of number of selected individuals per progeny $\left(\sigma_{k f}^{2}\right)$; effective number $\left(N_{e}\right)$; a: additive genetic effect = MEl: Multi-effect Index; selection gain $\left(S_{g}(\%)\right)$; genetic diversity $(\hat{D})$; general mean $(\mu)$. Source: The author

conditions in PG, such as frost occurrence may have contributed to performance of some families. These results indicate that the traits genetic control is high for average level, medium for individual level within families. Thus, the results show low environmental influence on phenotypic variation, which is important for the prediction of genetic gain by selection.

Heritability estimates vary with age, environment and species. Overall, estimates of mean family heritability for growth traits in pine species varies from 0.42 to 0.76 for $P$. caribaea var. bahamensis and P. elliottii (Missio et al., 2004; Romanelli and Sebbenn, 2004; Sebbenn et al., 2008). Olsson and Ericsson (2002) found low mean family heritability for six years old $P$. sylvestris progenies in Sweden. They also affirm that the estimate of this parameter increases as trial age. As a result, considering the age of the progeny tests, they showed good prediction for traits of economic importance, which is interesting when it aims early age selection.

Deviations in shape, caused by sinuosity, stem malformation, apex loss or damage, and even fork may decrease the volume and the value of economic parts of the stem increasing the price of handling and transportation (Codesido and Fernández-López, 2008). In this case, fork is not easily transmissible due to present lower $h_{a}^{2}$ in RB (0.05) and PG (0.07), possibly due to the lower incidence of forked trees (Fig. 6). Cotterill and Zed (1980) also found low $h_{a}^{2}$ for fork (0.02-0.04) in P. radiata progeny test.

The average of $h_{a}^{2}$ estimate varies considerably in relation to other pine species: Wu et al. (2008) for P. radiata found $h_{a}^{2}$ ranging from 0.02 to 0.57 ; Gwaze et al. (1997) for $P$. taeda from 0.13 to 0.55 and Weng et al. (2015) for Pinus banksiana from 0.11 to 0.22 .

Narrow-sense heritability for branch angle was 0.06 in RB and 0.17 in PG (Fig. 6). Similar results found by Arregui et al. (1999), Espinel and Aragones (1997) and Codesido and
Fernández-López (2008) in P. radiata. Taking everything into consideration, genetic selection for high heritabilities for both individual and family mean levels indicate that these families have evolutionary potential to respond to artificial changes, because significant part of genetic variability is from genetic origin.

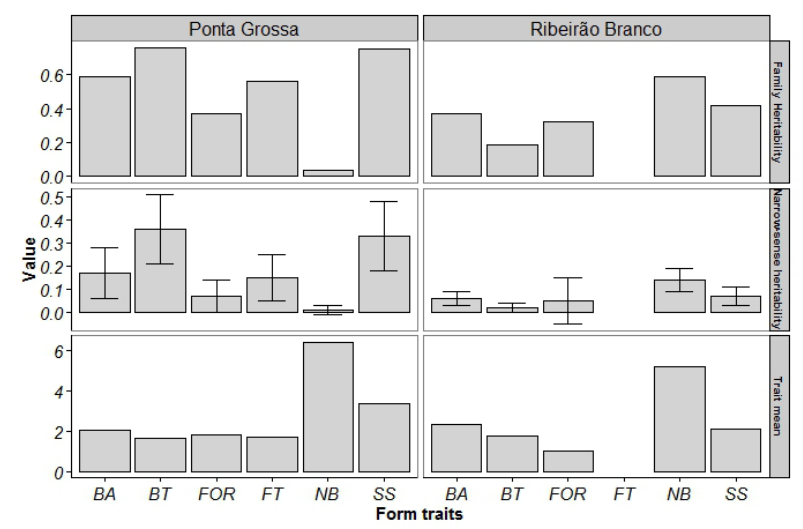

Figure 6

Narrow-sense individual heritability and family heritability mean for slash pine form traits in municipalities of Ribeirão Branco and Ponta Grossa, Brazil. BA: branch angle, BT: branch thickness, FOR: fork, FT: fox tail, NB: number of branches, SS: stem straightness 
Table 4

Estimate of genetic parameters and genotype $\mathrm{x}$ environment interaction for height, diameter at breast height (DBH), wood volume and stem straightness (SS) in four years old slash pine families in Ribeirão Branco-SP and Ponta Grossa-PR, Brazil

$\begin{array}{ccccc} & \begin{array}{c}\text { Height } \\ (\mathrm{m})\end{array} & \begin{array}{c}\text { DBH } \\ (\mathrm{cm})\end{array} & \begin{array}{c}\text { Volume } \\ \left(\mathrm{m}^{3} \text { tree }^{-1}\right)\end{array} & \text { SS } \\ h_{\alpha}^{2} & 0.03( \pm 0.01) & 0.02( \pm 0.01) & 0.05( \pm 0.01) & 0.02( \pm 0.01) \\ h_{m}^{2} & 0.60 & 0.53 & 0.62 & 0.53 \\ r_{\text {ăa }} & 0.77 & 0.73 & 0.79 & 0.73 \\ C_{\text {int }}^{2} & 0.01 & 0.01 & 0.04 & 0.00 \\ \mathrm{rb} & 0.72 & 0.61 & 0.58 & 0.89 \\ \mathrm{CV}_{\text {gi }}(\%) & 2.67 & 3.04 & 10.04 & 3.27 \\ \mathrm{CV}_{\mathrm{e}}(\%) & 15.57 & 19.42 & 41.93 & 25.23 \\ \mu & 5.86 & 10.92 & 0.03 & 2.10 \\ \mathrm{LRT} & 4.24^{*} & 3.00 \mathrm{~ns} & 5.13^{*} & 3.16 \mathrm{~ns}\end{array}$

Narrow sense individual heritability $\left(h_{a}^{2}\right)$; average heritability of progenies $\left(h_{m}^{2}\right)$; accuracy $\left(r_{\mathrm{a} a \mathrm{a}}\right)$; coefficient of determination of genotype $\mathrm{x}$ environment interaction ( $C_{\text {int }}^{2}$ ); genetic correlation between progenies between sites - type $b$ correlation $\left(r_{b}\right)$; coefficient of individual additive genetic variation $\left(\mathrm{CV}_{\mathrm{gi}}\right)$; coefficient of residual variation $\left(\mathrm{CV}_{\mathrm{e}}\right)$; general mean $(\mu)$; likelihood ratio test (LRT); significant to $1 \%\left({ }^{*}\right)$ with 1 degree of freedom; (ns) not significant.

\section{Effective sizes and expected selection gains}

Three selection strategies for each site was proposed base on individual BLUP (Table 3). This form of selection, enables, according to Resende and Higa (1994), explore fractions of additive genetic variance that are not considered in the selection among and within progenies, leading to accuracy selection maximization, although the inclusion of plot and blocks effects can change the selection. Strategy I selected 80 best trees from each site with intention to establish clonal seed orchards. In RB from 44 families, 19 were selected based on volume and eight based on stem straightness, in this way creating 21 and $15 \%$ of genetic diversity, respectively. In the other hand, from 24 families in PG trial, 15 were selected for both chosen traits, creating $31 \%$ of genetic diversity for both (Table 3). Predict selection gain $\left(S_{g}\right)$ was $8.6 \%$ for volume and $4.0 \%$ for stem straightness in RB and $23.5 \%$ for volume and $10.5 \%$ for stem straightness in PG. The higest genetic gain in PG is due to greater genetic variation in this site (Fig. 4 and 5).

Strategy II was to selecte two best trees per family to compose the next generation of tree improvement. As all progenies were selected, genetic diversity was $100 \%$ for both local and traits (Table 3). After thinning, $S_{g}$ was $4.9 \%$ for volume and $1.7 \%$ for stem straightness in RB, while in PG were $16.1 \%$ for volume and $7.6 \%$ for stem straightness. Adoption of blander selection intensity (strategy II) within progenies decreased the percentage of gain selection in both sites. However, PG still showed higher selection gains due to higher genetic variation.

Strategy III selected $50 \%$ of best trees per family, as previous selection all families were selected obtaining $100 \%$ of genetic diversity (Table 3). With a bland selection $S_{g}$ decreased for all traits and sites except for stem straightness in PG, where it is possible to see and increase for $S_{g}$ compared to the other strategy. Although intense selection used in Strategy I, it may lead to early elimination of important alleles, and result in genetic drift during genetic combination, although it increase the genetic gain.

\section{Age-age and trait-trait genetic and phenotypic correlation}

Coefficients of genetic correlation (Fig. 7) were positive and significant for all pairwise growth traits, ranging from 0.60 to 0.96 for different ages in RB. However, form traits presented

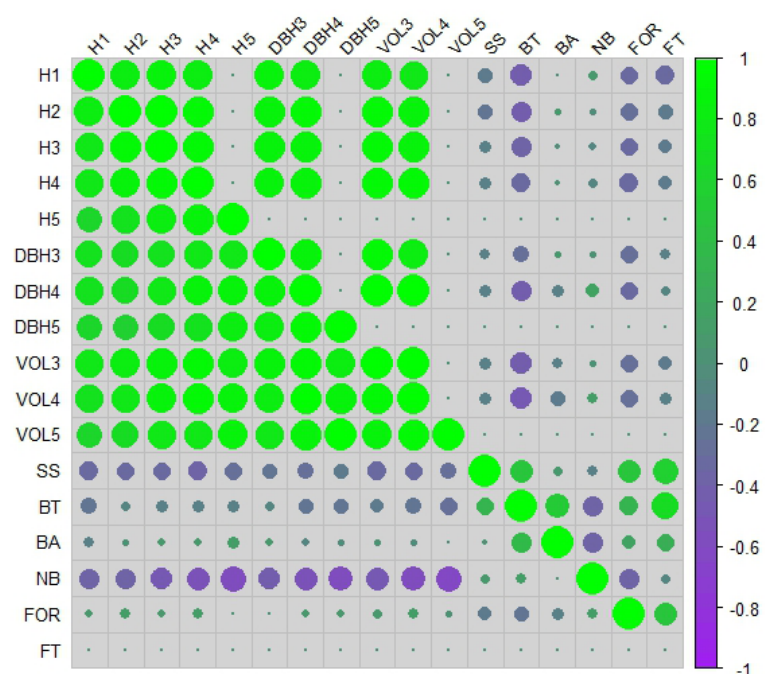

\section{Figure 7}

Estimates of genetic correlations (Ponta Grossa = above the diagonal, Ribeirão Branco = below the diagonal) between growth and forms traits for slash pine progenies in Brazil. $\mathrm{H} 1$, $\mathrm{H} 2, \mathrm{H} 3, \mathrm{H} 4$ and $\mathrm{H} 5$ = height at age one, two, three, four and five; $\mathrm{DBH} 3, \mathrm{DBH} 4$ and $\mathrm{DBH} 5$ = diameter at breast height at age three, four and five; VOL3, VOL4 and VOL5 = wood volume at age three, four and five; SS = stem straightness; BT = branch thickness; $\mathrm{BA}=$ branch angle; $\mathrm{NB}=$ number of branches; FOR $=$ fork

genetic correlation values with low to moderate magnitude, positive and negative, it include non-significant variables. PG presented positive and significant genetic correlation coefficients for all pairs of growth traits with values between 0.80 and 0.97 . Most of pairs with form traits showed negative genetic correlation and some not significant among it.

High and significant genetic correlation values between different assessments of height and dbh in early age indicate that both traits are controlled by the same group of genes and allows a great reliability in the early selection. According to Phillips et al. (2013) and Sant'Ana et al. (2013), when the selection is made on traits with positive and high magnitude correlation it is possible to achieve high correlated response occurring an advantage on selection. 
Table 5

Slash pine progenies selection based on wood volume for stability (MHVG), adaptability (PRVG) and simultaneously to productivity, stability and adaptability (MHPRVG), at 4 years of age in municipalities of Ribeirão Branco and Ponta Grossa, Brazil

\begin{tabular}{|c|c|c|c|c|c|c|c|c|}
\hline \multirow{2}{*}{$\begin{array}{l}\text { Stability } \\
\text { Family }\end{array}$} & \multirow[b]{2}{*}{ MHVG } & \multirow[b]{2}{*}{ Family } & \multirow{2}{*}{$\begin{array}{c}\text { Adaptabili } \\
\text { PRVG }\end{array}$} & \multirow[b]{2}{*}{ PRVG*MG } & \multicolumn{2}{|c|}{ Stability and adaptability } & \multirow[b]{2}{*}{ MH } & \multirow[b]{2}{*}{ PRVG*MG } \\
\hline & & & & & Family & MHPRVG & & \\
\hline C-197 & 0.034 & C-197 & 1.268 & 0.034 & C-197 & & 1.259 & 0.034 \\
\hline C-189-1 & 0.031 & C-189-1 & 1.165 & 0.032 & C-189-1 & & 1.162 & 0.032 \\
\hline C-084-2 & 0.031 & C-084-2 & 1.142 & 0.031 & C-084-2 & & 1.140 & 0.031 \\
\hline C-032-2 & 0.029 & C-032-2 & 1.083 & 0.029 & C-032-2 & & 1.083 & 0.029 \\
\hline$C-228$ & 0.029 & C-012-3 & 1.082 & 0.029 & C-012-3 & & 1.082 & 0.029 \\
\hline C-012-3 & 0.029 & $C-228$ & 1.079 & 0.029 & $C-228$ & & 1.079 & 0.029 \\
\hline$C-128-2$ & 0.029 & C-128-2 & 1.076 & 0.029 & $C-128-2$ & & 1.076 & 0.029 \\
\hline C-067-1 & 0.029 & C-067-1 & 1.054 & 0.029 & C-067-1 & & 1.053 & 0.029 \\
\hline C-083-1 & 0.027 & C-083-1 & 1.004 & 0.027 & C-016-2 & & 1.002 & 0.027 \\
\hline C-016-2 & 0.027 & C-016-2 & 1.003 & 0.027 & C-083-1 & & 1.000 & 0.027 \\
\hline C-048-2 & 0.027 & C-048-2 & 0.995 & 0.027 & C-048-2 & & 0.995 & 0.027 \\
\hline C-013 & 0.027 & C-013 & 0.979 & 0.027 & C-013 & & 0.979 & 0.027 \\
\hline C-068-1 & 0.027 & C-068-1 & 0.974 & 0.026 & C-068-1 & & 0.973 & 0.026 \\
\hline C- $-025-3$ & 0.026 & C-025-3 & 0.970 & 0.026 & C- $025-3$ & & 0.970 & 0.026 \\
\hline C-047-1 & 0.026 & C-047-1 & 0.966 & 0.026 & C-047-1 & & 0.966 & 0.026 \\
\hline C-019-1 & 0.026 & C-019-1 & 0.949 & 0.026 & C-019-1 & & 0.949 & 0.026 \\
\hline C-217-1 & 0.025 & $C-217-1$ & 0.935 & 0.025 & C-217-1 & & 0.935 & 0.025 \\
\hline C-036-1 & 0.025 & C-032-1 & 0.917 & 0.025 & C-032-1 & & 0.917 & 0.025 \\
\hline C-032-1 & 0.025 & C-010-1 & 0.915 & 0.025 & C-010-1 & & 0.915 & 0.025 \\
\hline C-010-1 & 0.025 & C-036-1 & 0.914 & 0.025 & C-036-1 & & 0.914 & 0.025 \\
\hline C-039-2 & 0.025 & C-039-2 & 0.908 & 0.025 & C-039-2 & & 0.906 & 0.025 \\
\hline C-023-1 & 0.024 & C-023-1 & 0.899 & 0.024 & C-023-1 & & 0.898 & 0.024 \\
\hline C-272-1 & 0.024 & C-272-1 & 0.892 & 0.024 & C-272-1 & & 0.892 & 0.024 \\
\hline$C-225$ & 0.023 & $C-225$ & 0.834 & 0.023 & $C-225$ & & 0.834 & 0.023 \\
\hline
\end{tabular}

Favourable genetic correlations were found between the growth traits and stem straightness and fork indicating the selection of trees with high growth rate will result in trees with straighter stems and no fork. These results have a practical implication, especially when the purpose is wood for sawing. Opposite result was found by Adams and Bastien (1994) in Pseudotsuga menziesii progenies and Cumbie et al. (2012) and Xiong et al. (2014) for P. taeda. For the same authors, positive genetic correlation between traits imply that improvement of one trait can automatically lead to the improvement of the other one.

Phenotypic correlations were strongly positive and significant between pairs of growth traits to both sites (Fig. 8). Exception was noted among fork and growth traits in RB. Selection on one trait of a pair that is controlled by genetic correlation caused by pleiotropic effects will also stimulate response in unselected trait. Since the correlations we report here are possibly of this nature, truncation selection to improve height or dbh in slash pine is expected to cause increased wood volume
(Roberds et al. 2003). Genetic correlations were mostly higher than phenotypic correlations to both sites. According Gwaze(2009), models based on phenotypic correlations will underestimate the genetic progress and unnecessarily delay selection. Similar results have also shown that difference in other species of conifers as loblolly pine (Gwaze and Bridgwater, 2002) and jack pine (Riemenschneider, 1988). For that reason, genetic correlations are important for making decision in forest breeding programs because, breeders may infer if a trait may affect the improvement of another. Evaluation of genetic correlation between traits is needed to determine whether there will be favourable or unfavourable benefits for breeding program and if these correlations are required for the determination of multi-trait selection index (Atwood et al., 2002). 


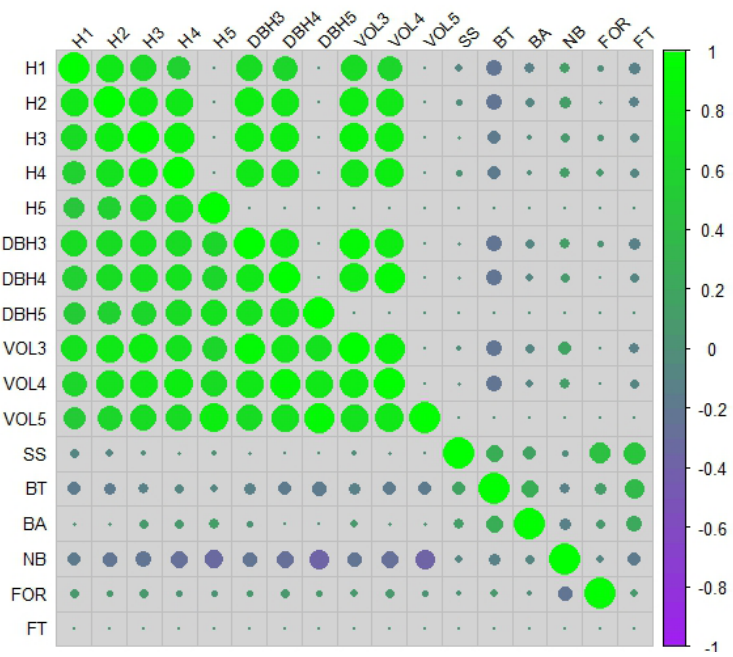

Figure 8

Estimates of phenotypic correlations (Ponta Grossa = above the diagonal, Ribeirão Branco = below the diagonal) between growth and forms traits for slash pine progenies in Brazil. H1, $\mathrm{H} 2, \mathrm{H} 3, \mathrm{H} 4$ and $\mathrm{H} 5=$ height at age one, two, three, four and five; $\mathrm{DBH} 3, \mathrm{DBH} 4$ and $\mathrm{DBH} 5$ = diameter at breast height at age three, four and five; VOL3, VOL4 and VOL5 = wood volume at age three, four and five; $\mathrm{SS}=$ stem straightness; $\mathrm{BT}=$ branch thickness; $\mathrm{BA}=$ branch angle; $\mathrm{NB}=$ number of branches; FOR = fork

\section{Joint analysis}

Likelihood ratio test (LRT) was significant only for height and volume for joint analysis, indicating that there are genetic differences for slash pine families in both sites (Table 4).

Individual narrow-sense heritability $\left(h_{a}^{2}\right)$ showed low magnitude for all traits (Table 4), reaffirming the differences between trees at sites. On the other hand, the estimate mean heritability among families $\left(h_{m}^{2}\right)$ were high $(>0.53-\mathrm{dbh}$, and steam straightness/SS) implying that most of total variation observed is from genetic origin leading to high estimates accuracy $\left(r_{\hat{a} a}>0.73-\mathrm{dbh}\right.$ and SS). These values show high genetic control and efficiency in a general selection involving two experiments, in case conjoint analysis be adopt as base.

Coefficients of genotype x environment interaction ( $\left.C_{i n t}^{2}\right)$, which quantifies the portion of the total variation (phenotypic), which is represented by the variation of $G \times E$ interaction, showed low values for all traits. However, it led to high magnitude of genetic correlation between the performance of progeny and environments ( $r_{b}$ - type b correlation, Table 4), suggesting low GxE interaction. Type B genetic correlations estimate genotypic performance correlation in different environments and provide an indication of the importance of $\mathrm{G} \times \mathrm{E}$ interaction (McKeand et al., 2006). Mulder et al. (2006) and Raymond (2011) affirm type b correlation levels should be greater than 0.60 to suggest an improvement level. Therefore, the situation is very favourable for application selection in both sites, in this case, height, dbh and stem. Similarly, Hodge and White
(1992) and Dieters et al. (1995) also found type b correlation values greater than 0.60 in five years old slash pine families. The same way, Jayawickrama (2001) and Baltunis and Brawner (2010) reported relatively high type-b genetic correlations in New Zealand, for different $P$. radiata families sites, for most important traits demonstrating open-pollinated families are well protected against environmental variation. However, authors affirm also that results interpretation should be viewed carefully, mainly, if the experiments cover a representative species plantation area. In general, this species present low genotype $x$ environment interaction, but the information that we have is not sufficiently to take good conclusion about this subject. P. elliottii is plating large region in Brazil in next generation is necessary to consider more hetereogenous planting area.

The coefficient of genetic variation $\left(C V_{g i}\right)$ was high only for volume $(10.0 \%)$ compared to the other traits (2.7\% - height, 3.0\% - dbh and $3.3 \%$ - SS) (Table 4). Martinez et al. (2012) also observed this tendency in loblolly pine families for height and $\mathrm{dbh}$. The authors assert that the variance components differences between joint and individual analysis is due to the fact that conjoint analysis generate average components between sites.

\section{Productivity, stability and adaptability}

Progeny ranking for both sites was similar being able to indicate the same progenies for both growing region. If the four best progenies were taken into consideration (E-197, E-189-1, E-084-2 and E-032-2) there is $100 \%$ of coincidence based on the adaptability (PRVG), stability (MHVG) and adaptability, stability and productivity criteria simultaneously (MHPRVG) for volume (Table 5). Although the selection order of 24 tested progenies at two sites was not exactly the same, the best progenies agreed for joint analysis, revealing that the most productive progenies are the most stable and present highest adaptability. The PRVG and MHPRVG values indicate the average genotype superiority in relation to the environmental in which it is grown (Resende, 2007b; Zeni Neto et al., 2008). For example, the best progeny (E-197) for wood production showed a superiority over 1.27 times the average of environment in which it is located. MHPRVG*MH value shows the average genotypic value of the progenies in the two sites, and this amount has already been penalized by instability and capitalized by adaptability (Carbonell et al., 2007). Environmental variations can interfere at GxE interactions, thus it is important and necessary to identify stable genotypes that produce well in various conditions (Gonçalves et al., 2003).

In general, there were not many changes in the ordering of progenies ( $79 \%$ of coincidence). This is due to the high correlation of progeny genetic behaviour on sites, therefore, it is suggested that the MHVG, PRVG and MHPRVG methods present ranking agreement for progenies and the use of this selection criteria confer improvement of selection in deducting secure genetic values predictions and concomitantly for productivity, stability and adaptability (Pinto Junior et al. 2006; Resende, 2007b).

For inferences about the expected productivity, the genotypic values should be considered as the characteristics of the 
planting site. If plantings are carried out in several other sites with varying GxE interaction patterns it should be considered the genotypic values (genetic means) for sites average, penalized by instability and capitalized by the adaptability (MHPRVG). In addition to these, MHVG values should be considered if the planting is done in others unknown sites or with different interaction of experimental network pattern or high heterogeneity within sites. If the sites present the same GxE interaction pattern of planting environment should be based on the sites average in order to capitalize the responsiveness of each progeny in relation to environment improving, PRVG values shall be prioritized. For planting in the same sites of the experiments consider the genotypic values (genetic means) of each local (individual analysis).

Taking everything into consideration, it is important to test a major number of families in major number of sites as possible to verify adaptability and stability of them in relation to next breeding cycles. With this practice will be possible to create plantations zones which could decreased time and increased productivity.

\section{Conclusions}

There are significant differences among open-pollinated progeny in RB and PG trials for growth trait. Considerable genetic variation, especially for wood volume.

High coefficients of genetic variation and heritability show low environmental influence on phenotypic variation, which is important for the prediction of genetic gain by selection.

The predict genetic gain in selection for volume and tem straightness are expected be highest in PG when higher intensity is applied aiming clonal orchard formation.

Positive and significant genetic correlation were found for all pairwise growth traits ranging for different ages in RB and PG. In relation to form traits, values with low to moderate magnitude, positive and negative for both site were found.

The effect of GxE interaction is the simple type. The plantations made in several other sites with varying GxE interaction patterns should consider MHPRVG effect, prioritizing the most productive families, stable and high adaptability.

Genotypes such as C-197, C-189-1, C-084-2 and C-032-2 are indicated to plantations in both São Paulo and Paraná states according to stability (MHVG), adaptability (PRVG) and simultaneously productivity, stability and adaptability (MHPRVG).

\section{Acknowledgments}

Authors would like to thank Coordination for the Improvement of Higher Education Personnel - CAPES - by granting scholarship throughout agreement signed with Embrapa Forests, Pinara Reforestation and Management Company for seedlings production and field trials management, Embrapa Forests technicians for experiment installation and conduction and trainee Matheus Theodorovicz for their assistance in field data.

\section{References}

Adams WT, BASTIEN JC (1994) Genetics of second flushing in a French plantation of coastal Douglas-fir. Silvae Genetica 43 (5):345-352.

Aguiar AV, Souza VA, Shimizu JY (2010) Seleção genética de progênies de Pinus greggii para formação de pomares de sementes. Pesquisa Agropecuária Brasileira 30 (62): 107-117. Available at https://doi.org/10.4336/2010. pfb.30.62.107

Arregui A, Espinel S, Aragonés A, Grado RS (1999) Estimación de prámetros genéticos em um ensayo de progenies de Pinus radiata $D$. Don en el País Vasco. Investigacíon Agraria: Sistemas y Recursos Forestales 8 (1): 119-128.

Alwala S, Kwolek T, McPherson M, Pellow J, Meyer D (2010) Comprehensive comparison between Eberhart and Russell joint regression and GGE biplot analyses to identify stable and high yielding maize hybrids. Field Crops Research 119 (2): 225-230. Available at https://doi.org/10.1016/j. fcr.2010.07.010

Atwood RA, White TL, Huber D A (2002) Genetic parameters and gain for growth and wood properties in Florida source loblolly pine in the southeastern United State. Canadian Journal of Forest Research 32 (5): 1025-1038. Available at https://doi.org/10.1139/×02-025

Baltunis BS, Brawner JT (2010) Clonal stability in Pinus radiata across New Zealand and Australia. I. Growth and form traits. New Forests 40 (3): 305-322. Available at https://doi.org/10.1007/s11056-010-9201-4

Carbonell SAM, Chiorato AF, Resende MDV, Dias LAS, Beraldo ALA, Perina EF (2007) Estabilidade em cultivares e linhagens de feijoeiro e diferentes ambientes no estado de São Paulo. Bragantia 66 (2): 193-201.

Codesido V, Fernández-López J (2008) Juvenile genetic parameter estimates for vigour, stem form, branching habit and survival in three radiate pine (Pinus radiate D. Don) progeny test in Galicia, NW Spain. European Journal of Forest Research 127 (4): 315-325. Available at https://doi.org/10.1007/s10342008-0207-9

Cotterill PP, Zed PG (1980) Estimates of genetic parameters for growth and form traits in four Pinus radiata D. Don progeny tests in South Australia. Australia Forest Research 10 (2): 155-167.

Cruz CD (2006) Programa Genes: Análise Multivariada e Simulação. Viçosa: UFV, 175 p, ISBN 13:9788572692489.

Cruz CD. Regazzi AJ, Carneiro PCS (2004) Modelos biométricos aplicados ao melhoramento genético. Viçosa: UFV, 514 p, ISBN 13:9788572694339.

Cumbie WP, Isik FT, Mckeand SE (2012) Genetic improvement of saw timber potential in loblolly pine. Forest Science 58 (2): 168-177. Available at https:// doi.org/10.5849/forsci.09-060

Dieters MJ (1996) Genetic parameters for slash pine (Pinus elliottii) grown in south-east Queensland, Australia: Growth, steam straightness and crown defects. Forest Genetics 3 (1): 27-36.

Dieters MJ, White TL, Hodge GR (1995) Genetic parameter estimates for volume from full-sib testes of slash pine (Pinus elliottii). Canadian Journal of Forest Research 25 (5): 1397-1408. Available at https://doi.org/10.1139/x95-152

Dorman KW, Squillace AE (1974) Genetics of slash pine. USDA Forest Service Research Paper 20 (1): 01-20. Available at https://doi.org/10.5962/bhl.title.87841

Espinel S, Aragonés A (1997) Genetic parameters for Pinus radiata D.Don in Basque Country. New Zealand Journal Forest Science 27 (3): 272-279.

Ettori LC (2004) Variação genética em procedências e progênies mexicanas de Pinus maximinoi. Revista do Instituto Florestal 16 (1): 01-09.

Falconer DS, Mackay TFC (1996) Introduction to quantitative genetics. London: Longman Group Ltd., 464 p, ISBN 0582243025

Freitas MLM, Zanatto ACS, Morais E, Lemos SV, Fernandes AC, Sebbenn AM (2005) Estimativa de parâmetros genéticos e ganhos na seleção em Pinus caribaea var. bahamensis, aos 22 anos de idade. Revista do Instituto Florestal 17 (1): 103-111.

Fries A (2012) Genetic parameters, genetic gain and correlated responses in growth, fibre dimensions and wood density in a scots pine breeding population. Annals of Forest Science 69 (1): 783-794. Available at https://doi. org/10.1007/s13595-012-0202-7

Gapare WJ, Ivković M, Dutkowski GW, Spencer DJ, Buxton P, Wu HX (2012) Genetic parameters and provenance variation of Pinus radiata D. Don. 'Eldridge collection' in Australia 1: growth and form traits. Tree Genetics \& Genomes 8 (4): 391-407. Available at https://doi.org/10.1007/

s11295-011-0449-4 
Gonçalves PS, Bortoletto N, Fonseca FS, Bataglia OC, Ortolani AA (1998) Early selection for growth vigor in rubber tree genotypes in northwestern São Paulo state (Brazil). Genetics and Molecular Biology 21(4): 620-630. Available at https://doi.org/10.1590/s1415-47571998000400018

Gonçalves PS, Bortoletto N, Martins ALM, Costa RB, Gallo PB (2003) Genotype-environment interaction and phenotypic stability for girth growth and rubber yield of Hevea clones in São Paulo State, Brazil. Genetics and Molecular Biology 26 (4): 441-448. Available at https://doi.org/10.1590/s1415 47572003000400007

Gwaze DP (2009) Optimum selection age for height in shortleaf pine. New Forests 37 (1): 9-16. Available at https://doi.org/10.1007/s11056-008-9104-9 Gwaze DP, Bridgwater FE (2002) Determining optimum selection age for diameter and height in loblolly pine (Pinus taeda). Forest Genetics 9 (2): 159165.

Gwaze D , Woolliams J , Kanowski PJ (1997) Genetic parameters for height and stem straightness in Pinus taeda L. in Zimbabwe. Forest Genetics 4 (2): 159169.

Hodge GR, White TL (1992) Genetic parameter estimates for growth traits at diferente ages in slash pine and some implications for breeding. Silvae Genetica 41 (5): 252-262.

Jayawickrama KJS (2001) Genetic parameter estimates for radiata pine in New Zealand and New South Wales: a synthesis of results. Silvae Genetica 50 (2): 45-53.

Lambeth CC (1980) Juvenile-mature correlations in Pinaceae and implications for early selection. Forest Science 26 (4): 571-580.

Martinez DT, Resende MDV, Costa RB, Higa AR, Santos GA, Fier ISN (2012) Estudo da interação genótipo $x$ ambiente em progênies de Pinus taeda por meio da análise de parâmetros genéticos. Revista Floresta 42 (3): 539-552. Available at https://doi.org/10.5380/rf.v42i3.20115

Martins-Corder MP, Mori ES, Kageyama PY, Lopes CR (1996) Estudo da variabilidade Isoenzimática em Eucalyptus urophylla S.T.Blake das Ilhas Flores. Revista do Instituto Instituto de Pesquisas e Estudos Florestais 50 (1): 43-49.

Matheson A, Spencer DJ, Magnussen D (1994) Optimum age for selection in Pinus radiata using basal area under bark for age-age correlations. Silvae Genetica 43 (5): 352-357.

Mckeand SE (1998) Optimum age for family selection for growth in genetic test of loblolly pine. Forest Science 34 (4): 400-411.

Mckeand SE, Jokela EJ, Huber DA, Byram TD, Allen HL, Li B, Mullin TJ (2006) Performance of improved genotypes of loblolly pine across different soils, climates, and silvicultural inputs. Forest Ecology and Management 227 (4): 178-184. Available at https://doi.org/10.1016/j.foreco.2006.02.016

Miranda AC, Moraes MLT, Silva PHM, Sebbenn AM (2015) Ganhos de seleção pelo método do índice multi-efeitos em progênies polinização livre de Eucalyptus grandis Hill ex Maiden. Scientia Forestalis 43 (105): 01-07.

Missanjo E, Kamanga-Thole G, Manda V (2013) Estimation of genetic and phenotypic parameters for growth traits in a clonal seed orchard of Pinus kesiya in Malawi. ISRN Forestry, 2013 (1): 1-6. Available at https://doi. org/10.1155/2013/346982

Missio RF, Cambuim J, Moraes MLT, Paula RC (2004) Seleção simultânea de caracteres em progênies de Pinus caribaea Morelet var. bahamensis. Scientia Forestalis 66 (2): 161-168.

Mulder HA, Veerkamp RF, Ducro BJ, Arendonk JA, Bijma P (2006) Optimization of dairy cattle breeding programs for different environments with genotypes by environment interaction. Journal Dairy Science 89 (5): 1740-1752. Available at https://doi.org/10.3168/jds.s0022-0302(06)72242-1

Nanson A (1970) Juvenile and correlated trait selection and its effect on selection programs. In: Proceedings of Second Meeting of Working Group on Quantitative Genetics IUFRO, Louisina, pp. 17-25.

Olsson T, Ericsson T (2002) Genetic Parameter Estimates of Growth and Survival of Pinus sylvestris with Mixed Model Multiple-trait Restricted Maximum Likelihood Analysis. Scandinavian Journal of Forest Research 17 (1): 103110. Available at https://doi.org/10.1080/028275802753626746

Pereira AB, Marques Junior OG, Ramalho MAP, Althoff P (1997) Eficiência da seleção precoce em famílias de meios-irmãos de Eucalyptus camaldulensis Dehnh, avaliadas na região noroeste do estado de Minas Gerais. Cerne 3 (1): 67-81.

Pimentel-Gomes F, Garcia CH (2002) Estatística aplicada a experimentos agronômicos e florestais: exposição com exemplos e orientações para uso de aplicativos. Piracicaba: FEALQ, 309 p, ISBN 85-7133-014-X.
Pimentel FG (2000) Curso de estatística experimental. Piracicaba: FEALQ, 451 p, ISBN 978-85-7133-055-9.

Pinto Júnior, JE, Sturion JA, Resende MDV, Ronzelli Júnior P (2006) Avaliação simultânea de produtividade, adaptabilidade e estabilidade genotípica de Eucalyptus grandis em distintos ambientes do estado de São Paulo. Boletim de Pesquisa Florestal 53 (1): 79-108.

Pswarayi, IZ, Barnes RD, Birks JS, Kanowski PJ (1996) Genetic parameter estimate for production and quality traits of Pinus elliottii Engelm. var. elliottii in Zimbabwe. Silvae Genetica 45 (4): 216-222

Raymond CA (2011) Genotype by environment interactions for Pinus radiata in New Wales, Australia. Tree Genetics Genomes 7 (4): 819-833. Available at https://doi.org/10.1007/s11295-011-0376-4

Resende MDV (2007b) Matemática e estatística na análise de experimento e no melhoramento genético. Colombo: Embrapa Florestas, 362 p, ISBN 9788589281157

Resende MDV (2007a) Software SELEGEM - REML/BLUP: sistema estatístico e seleção genética computadorizada via modelos lineares mistos. Colombo: Embrapa Florestas, 359 p, ISBN 9788589281164.

Resende MDV, Araújo AJ, Sampaio PTB, Wiecheteck MDS (1995) Acurácia seletiva, intervalos de confiança e variâncias de ganhos genéticos associados a 22 métodos de seleção de Pinus caribaea var. hondurensis. Revista Floresta 25 (1): 03-16. Available at https://doi.org/10.5380/rf.v25i12.6444

Resende MDV, Higa AR (1994) Maximização da eficiência da seleção em testes de progênies de Eucalyptus através da utilização de todos os efeitos do modelo matemático. Boletim de Pesquisa Florestal 29: 37-55.

Riemenschneider DE (1988) Heritability, age-age correlations, and inferences regarding juvenile selection in jack pine. Forest Science 34 (4): 1076-1082.

Roberds JH, Strom BL, Hain FP, Gwaze DP, Mckeand SE, Lott LH (2003) Estimates of genetic parameters for oleoresin and growth traits in juvenile loblolly pine. Canadian Journal of Forest Reearch 33 (5): 2469-2476. Available at https://doi.org/10.1139/x03-186

Romanelli RC, Sebbenn AM (2004) Parâmetros genéticos e ganhos na seleção para produção de resina em Pinus elliottii var. elliottii, no Sul do Estado de São Paulo. Revista do Instituto Florestal 16 (1): 11-23.

Sant'ana VZ, Freitas MLM, Moraes MLT, Zanata M, Zanatto ACS, Moraes MA, Sebbenn AM (2013) Parâmetros genéticos em progênies de polinização aberta de Enterolobium contortisiliquum (Vell.) Morong em Luiz Antonio, SP, Brasil. Hoehnea 40 (3): 515-520. Available at https://doi.org/10.1590/s2236$\underline{89062013000300011}$

Schultz RP (1997) Loblolly pine: the ecology and culture of loblolly pine (Pinus taeda L.). Washington: U.S. Department of Agriculture, Forest Service, $493 \mathrm{p}$

Sebbenn AM, Vilas Bôas O, Max JCM (2010) Altas herdabilidades e ganhos na seleção para caracteres de crescimento em teste de progênies de polinização aberta de Pinus elliottii Engelm var. elliottii aos 25 anos de idade em Assis-SP. Revista do Instituto Florestal 20 (2): 95-102.

Sebbenn AM, Freitas MLM, Morais E, Zanatto ACS (2005) Variação genética em procedências e progênies de Pinus patula ssp. tecunumanii no noroeste do Estado de São. Revista do Instituto Florestal 17 (1): 01-15.

Silva GAP, Gouvêa LRL, Verardi CK, Oliveira ALB, Goncalves PS (2014) Annual growth increment and stability of rubber yield in the tapping phase in rubber tree clones: Implications for early selection. Industrial Crops and Products 52 (4): 801-808. Available at https://doi.org/10.1016/j.indcrop.2013.12.010

Silva JM, Aguiar AV, Mori ES, Moraes MLT (2011) Variação genética e ganho espe rado na seleção de progênies de Pinus caribaea var. caribaea em Selvíria, MS. Scientia Forestalis 39 (90): 241-252.

Silva WCJ, Duarte JB (2006) Métodos estatísticos para estudo de adaptabilidade e estabilidade fenotípica em soja. Pesquisa Agropecuária Brasileira 41 (1): 23-30. Available at https://doi.org/10.1590/s0100-204×2006000100004

United States Department Of Agriculture - USDA (2016) Slash Pine. Pinus elliotti Engelm [on line]. United States of America, to be found at $<$ http://plants. usda.gov/plantguide/pdf/pg_piel.pdf> [quoted, 01.10.2016].

Weng YH, Lu P, Adams GW, Fullarton MS, Tosha KJ (2015) Genetic paramenters of growth and stem quality traits for jack pine second-generation progeny tested in New Brunswick. Canadian Journal of Forest Research 45 (1): 36-43. Available at https://doi.org/10.1139/cjfr-2014-0106

White TL, Adams WT, Neale DB (2007) Forest genetics. Wallingford: CABI, 500 , ISBN 978-0851993485. Available at https://doi. org/10.1079/9781845932855.0000 
Wu HX, Ivković M, Gapare WJ, McRae TA (2008) Breeding for wood quality and profit in radiate pine: a review of genetic parameters and implication for breeding and deployment. New Zealand Journal of Forest Science 38 (1): 56-87.

Xiong JS, McKeand SE, Whetten RW, Isik FT (2014) Genetics of steam forking and ramicorn branches in a clonal loblolly pine family. Forest Science 60 (5): 360-366. Available at https://doi.org/10.5849/forsci.12-018

Xiong JS, Isik FT, McKeand SE, Whetten RW (2010) Genetic variation of steam forking in loblolly pine. Forest Science 56 (5): 429-436.

Yang H, Liu T, Liu C, Wang J, Chen K, Zhong W, Chen B, Huang S (2013) Genetic parameters and efficiency of early selection for half rotation-aged growth and form traits in Pinus taeda in China. Silvae Genetica 62 (6): 277-284.

Zeni Neto H, Oliveira RA, Daros E, Bespalhok Filho JC, Zambon JLC, Ido OT, Weber $\mathrm{H}$ (2008) Seleção para produtividade, estabilidade e adaptabilidade de clones de cana-de-açúcar em três ambientes no estado do Paraná via modelos mistos. Scientia Agraria 9 (4): 425-430. Available at https://doi. org/10.5380/rsa.v9i4.12475

Zobel BJ (1961) Inheritance of wood properties in conifers. Silvae Gnetica, 10 (3): 67-70. 